\title{
Beyond Beta-Delta: The Emerging Economics of Personal Plans
}

\section{Citation}

Beshears, John, Katherine L. Milkman, and Joshua Schwartzstein. "Beyond Beta-Delta: The Emerging Economics of Personal Plans." American Economic Review: Papers and Proceedings 106, no. 5 (May 2016): 430-434.

\section{Published Version}

https://www.aeaweb.org/articles?id=10.1257/aer.p20161100

\section{Permanent link}

http://nrs.harvard.edu/urn-3:HUL.InstRepos:32725818

\section{Terms of Use}

This article was downloaded from Harvard University's DASH repository, and is made available under the terms and conditions applicable to Open Access Policy Articles, as set forth at http:// nrs.harvard.edu/urn-3:HUL.InstRepos:dash.current.terms-of-use\#OAP

\section{Share Your Story}

The Harvard community has made this article openly available.

Please share how this access benefits you. Submit a story.

Accessibility 


\title{
Beyond Beta-Delta: The Emerging Economics of Personal Plans
}

\author{
By John Beshears, Katherine L. MiLKMAn ANd Joshua Schwartzstein*
}

\begin{abstract}
* Beshears: Harvard Business School, Baker Library, Soldiers Field, Boston, MA 02163 (e-mail: jbeshears@hbs.edu). Milkman: The Wharton School, The University of Pennsylvania, 566 Jon M. Huntsman Hall, 3730 Walnut Street, Philadelphia, PA 19103 (e-mail: kmilkman@wharton.upenn.edu). Schwartzstein: Harvard Business School, Baker Library, Soldiers Field, Boston, MA 02163 (e-mail: jschwartzstein@hbs.edu). We thank Tristan Gagnon-Bartsch, Sendhil Mullainathan, Alex Rees-Jones, and Richard Thaler for their helpful comments.
\end{abstract}

In his book Misbehaving: The Making of Behavioral Economics, Richard Thaler writes about "Supposedly Irrelevant Factors" (SIFs), or factors that observably affect economic decisions but are neglected by neoclassical models of consumer behavior (Thaler 2015). In this article, we highlight an important SIF that is neglected not only by neoclassical models, but also by now-standard behavioral economics models like the beta-delta model of time discounting (Laibson 1997). That SIF is a "personal plan."

For example, consider someone who has the opportunity to engage in a preventive health action, such as obtaining a flu shot or a cancer screening. If she has beta-delta preferences, she may fail to take the action because it entails up-front costs (inconvenience and discomfort) and delayed benefits (improved future health), even though she may deem the action to be in her overall best interest when she judges it before the opportunity for action arises. According to the beta-delta model, techniques for increasing the likelihood that this individual will take the preventive health measure include reducing the up-front costs or offering her a commitment device. Recent field studies, however, have documented the success of another technique. Simply prompting people to form concrete plans of action regarding when, where, and how they will implement their intentions produces improvements in follow-through, even when such prompts do not alter the costs and benefits of the action or change the opportunities for using commitment strategies (Milkman et al. 2011, 2013).

People make personal plans frequently (e.g., they write "to do" lists, keep calendars, and set deadlines). Many popular books, like Getting Things Done: The Art of Stress-Free Productivity, are devoted to the topic (Allen 2002). However, personal plans for future actions play a limited role in traditional economic analyses of individual decision 
making. Neoclassical models typically treat a personal plan as nothing more than an agent's (correct) understanding of the actions she will take in every possible future contingency.

Plans become more interesting when agents' actions deviate in predictable ways from those plans (see Milkman, Rogers, and Bazerman 2008 for one review), for example as a consequence of beta-delta intertemporal discount functions (Laibson 1997) or the conflicting preferences of "multiple selves" (Thaler and Shefrin 1981). If an analyst were looking for the object in these models that most closely resembles a personal plan, she might point to the agent's most preferred complete contingent future course of action. Alternatively, she might point to the agent's beliefs about the course of action the agent will take, regardless of the accuracy of those beliefs (O’Donoghue and Rabin 1999).

In this article, we adopt a third perspective that emphasizes how personal plans can play a more direct role in influencing behavior, and not only to overcome self-control problems: the simple act of planning to take an action can increase the likelihood of taking that action. An individual may not form a concrete plan in the first place. If the individual does form a plan, it may correspond neither to preferred future actions nor to beliefs about future actions because, for example, such a plan allows her to implement a personal management strategy that counteracts limited attention. An individual may also form a plan for less sophisticated reasons, and such a plan may become self-fulfilling. For example, a person who arbitrarily plans to order chicken at a restaurant (perhaps because she recently saw an advertisement for chicken) may be more likely to end up choosing chicken over fish because the plan creates a reference point from which she is reluctant to deviate (Kahneman and Tversky 1979, Köszegi and Rabin 2006).

We are not the first to take up personal plans as the subject of economic inquiry, but we wish to highlight the important yet underappreciated role of plans in driving economic outcomes. We organize our discussion by considering three questions. First, what are the effects of plans on behavior? Second, when are plans formed? Third, how do plans deviate from optimality? For each of these questions, we (a) offer a brief overview of existing research that sheds light on the issue and (b) identify gaps in current knowledge. We emphasize connections to the growing theoretical literature that gives personal plans a substantive role, but we conclude that more research is needed, especially on the latter two questions we cover. 


\section{What Do Plans Do?}

We discuss three ways in which plans affect behavior.

First, planning helps us overcome barriers to following through on our intentions. The planning prompts mentioned above have been shown to improve follow-through in domains ranging from voting (Nickerson and Rogers 2009) to obtaining flu shots (Milkman et al. 2011). One barrier to follow-through that planning prompts help people overcome is the failure to attend to logistics (e.g., arranging childcare in order to visit the doctor). Contemplating logistical hurdles in advance makes it easier to develop strategies for working around them. Another barrier to follow-through that planning prompts help people address is forgetfulness. Encouraging people to articulate a plan embeds intentions more firmly in memory by prompting deeper processing and attention. Planning prompts also associate cues like the intended execution time with the need to act. In line with this reasoning, planning prompts are particularly effective among populations at higher risk for forgetfulness, such as the elderly and parents (Milkman et al. 2013). ${ }^{1}$

\footnotetext{
1 Models of "thinking ahead" in economics include Bolton and Faure-Grimaud (2009).

2 Models of personal rules in economics include Benabou and
}

Second, plans create goals or personal rules with the purpose of helping people follow through on their intentions. A large literature demonstrates that setting a challenging, yet attainable, explicit goal increases achievement, even in the absence of external incentives (Locke and Latham 1990). One force at play is people's strong desire to be internally consistent and thus to avoid breaking explicit commitments (Festinger 1962). In addition, people may be reluctant to fall short of goals, which could become reference points, because of loss aversion (Heath, Larrick, and Wu 1999). ${ }^{2,3}$

Third, plans influence behavior because they frame decisions even when they are not formed with the objective of increasing follow-through. To take an example, models of expectations-based reference dependence predict a stronger taste for buying insurance when the opportunity to buy is anticipatedand a plan to buy is made - than when it is not, since expected premium payments are

\footnotetext{
2 Models of personal rules in economics include Benabou and Tirole (2004) and Hsiaw (2013).

3 One particularly interesting class of personal rules has been dubbed "mental accounting." Mental accounting describes the tendency to treat time and money as if they are not fungible but instead belong to distinct accounts that can only be used for a predetermined purpose or during a pre-determined time interval (Thaler 1985). By creating mental budget limits (e.g., "I will only spend $\$ 3,000$ on leisure travel this year"), people may be able to overcome the impulse to splurge on temptations.
} 
then not coded as a loss (Köszegi and Rabin 2006, 2007). ${ }^{4}$

\section{When Do People Form Plans?}

The research described in the previous section highlights the effects of plans on behavior, but it largely leaves open the question of when people form plans. People do not update their plans continuously. One model is that individuals update their plans at regular intervals on a fixed schedule (Gabaix and Laibson 2002). Another is that individuals incur cognitive costs from planning and choose when to plan by trading off those cognitive costs against the benefits of optimizing their decisions (Reis 2006). Both models likely contain some truth, but research in psychology indicates that planning takes place on a more nuanced schedule.

Research on the "fresh start effect" has shown that people are more likely to engage in self-controlled acts, such as planning, at the start of new cycles like the beginning of the week, month, or year and following holidays and birthdays. People search more for the term

\footnotetext{
4 Plans also matter in models where the choice context influences how attributes of different options are weighed (Bordalo, Gennaioli, and Shleifer 2013; Köszegi and Szeidl 2013; Bushong, Rabin, and Schwartzstein 2015) because this context can be shaped by the timing of when an agent forms her plan. For example, in the Bushong et al. model of relative thinking, a worker is less willing to put in effort for a fixed return in an environment where she expected to earn more at the time of making her plan, since this makes the return feel small. The model suggests that she would be more inclined to put in effort if, prior to making a plan, she received a more precise signal about returns.
}

"diet" on Google and create personal goals at a higher rate following these fresh start dates (Dai, Milkman, and Riis 2014). At the start of a new cycle, people perceive that their previous failings occurred in the more distant past, and this greater psychological distance creates an opportunity to break with bad patterns of behavior and form new, optimistic plans (Dai, Milkman, and Riis 2015).

Past research in psychology has also shown that life shocks (e.g., job changes) that alter a person's surroundings and routines often induce changes to plans (Wood et al. 2005). In many cases, the timing of the plan change is rational, but there is also evidence that people update their plans when predictable shocks to their circumstances occur, such as when a job seeker exhausts unemployment insurance benefits (Ganong and Noel 2015).

\section{How Do Plans Deviate from Optimality?}

Projection bias (Loewenstein, O’Donoghue, and Rabin 2003), naïveté about self-control problems (O’Donoghue and Rabin 1999), and overconfidence in one's ability to remember to take actions (Ericson 2011) may all lead people to form suboptimal plans. ${ }^{5}$

\footnotetext{
5 People also form overly optimistic plans, thinking they will get more done than they actually do (Buehler, Griffin, and Ross 1994).
} 
As a consequence, people's plans often fail to incorporate adequate mechanisms for shaping future behavior. For example, forgetting to take your medication is partly attributable to forgetfulness, but also partly due to a failure to make plans that compensate for forgetfulness. We can set alarms to take our pills, but many of us do not, contributing to low adherence (Osterberg and Blaschke 2005; Baicker, Mullainathan, and Schwartzstein 2015). Along these lines, many people are unwilling to pay to have a cue that serves as an effective reminder for engaging in a beneficial behavior, even when the cue leads to higher economic payoffs net of its cost (Rogers and Milkman 2015). Also, the fact that planning prompts can be effective (as discussed above) suggests that people do not always form effective plans (Milkman et al. 2011).

\section{Conclusion}

People often develop personal plans to help themselves follow through on their intentions. Plans can also influence behavior by shaping reference points and how decisions are framed. However, a complete account of the role of plans in economic decision making will require deeper knowledge of when and how plans are formed.
There are also important open questions regarding how best to measure plans, as eliciting a plan may alter it or cause it to be created in the first place. Despite this challenge, our understanding of the role of plans in driving economic outcomes would be greatly enriched by considering whether, when, where, and how people intend to take actions and collecting more data on these questions.

\section{REFERENCES}

Allen, David. 2002. Getting Things Done: The Art of Stress-Free Productivity. London: Penguin Books.

Baicker, Katherine, Sendhil Mullainathan, and Joshua Schwartzstein. 2015. "Behavioral Hazard in Health Insurance." Quarterly Journal of Economics 130 (4): 1623-1667.

Benabou, Roland, and Jean Tirole. 2004. "Willpower and Personal Rules." Journal of Political Economy 112 (4): 848-886.

Bolton, Patrick, and Antoine FaureGrimaud. 2009. "Thinking Ahead: The Decision Problem." The Review of Economic Studies 76 (4): 1205-1238.

Bordalo, Pedro, Nicola Gennaioli, and Andrei Shleifer. 2013. "Salience and Consumer Choice." Journal of Political Economy 121 (5): 803-843. 
Buehler, Roger, Dale Griffin, and Michael

Ross. 1994. "Exploring the 'Planning Fallacy': Why People Underestimate Their Task Completion Times." Journal of Personality and Social Psychology 67 (3): 366-381.

Bushong, Benjamin, Matthew Rabin, and Joshua Schwartzstein. 2015. "A Model of Relative Thinking." Working Paper.

Dai, Hengchen, Katherine L. Milkman, and Jason Riis. 2014. "The Fresh Start Effect: Temporal Landmarks Motivate Aspirational Behavior." Management Science 60 (10): 2563-2582.

Dai, Hengchen, Katherine L. Milkman, and Jason Riis. 2015. "Put Your Imperfections Behind You: Temporal Landmarks Spur Goal Initiation When They Signal New Beginnings." Psychological Science 26(12): 1927-1936.

Ericson, Keith M. Marzilli. 2011. "Forgetting We Forget: Overconfidence and Memory." Journal of the European Economic Association 9 (1): 43-60.

Festinger, Leon. 1962. A Theory of Cognitive Dissonance. Stanford: Stanford University Press.

Gabaix, Xavier, and David Laibson. 2002. "The 6D Bias and the Equity-Premium Puzzle." NBER Macroeconomics Annual 16: $257-312$.
Ganong, Peter, and Pascal Noel. 2015. "How Does Unemployment Affect Consumer Spending?" Working Paper.

Heath, Chip, Richard P. Larrick, and George Wu. 1999. "Goals as Reference Points." Cognitive Psychology 38 (1): 79109.

Hsiaw, Alice. 2013. "Goal-Setting and SelfControl." Journal of Economic Theory 148 (2): 601-626.

Kahneman, Daniel, and Amos Tversky. 1979. "Prospect Theory: An Analysis of Decision Under Risk.” Econometrica 47 (2): 263-291.

Kőszegi, Botond, and Matthew Rabin. 2006. "A Model of Reference-Dependent Preferences." Quarterly Journal of Economics 121 (4): 1133-1165.

Kőszegi, Botond, and Matthew Rabin. 2007. "Reference-Dependent Risk Attitudes." American Economic Review 97 (4): 1047-1073.

Kőszegi, Botond, and Adam Szeidl. 2013. "A Model of Focusing in Economic Choice." Quarterly Journal of Economics 128 (1): 53-107.

Laibson, David. 1997. "Golden Eggs and Hyperbolic Discounting." Quarterly Journal of Economics 112 (2): 443-477.

Locke, Edwin A., and Gary P. Latham. 1990. A Theory of Goal Setting and Task 
Performance. Englewood Cliffs: PrenticeHall.

Loewenstein, George, Ted O'Donoghue, and Matthew Rabin. 2003. "Projection Bias in Predicting Future Utility." Quarterly Journal of Economics 118 (4): 1209-1248.

Milkman, Katherine L., John Beshears, James J. Choi, David Laibson, and Brigitte C. Madrian. 2011. "Using Implementation Intentions Prompts to Enhance Influenza Vaccination Rates." Proceedings of the National Academy of Sciences of the United States of America 108 (26): 10415-10420.

Milkman, Katherine L., John Beshears, James J. Choi, David Laibson, and Brigitte C. Madrian. 2013. "Planning Prompts as a Means of Increasing Preventive Screening Rates." Preventive Medicine 56 (1): 92-93.

Milkman, Katherine L., Todd Rogers, and Max H. Bazerman. 2008. "Harnessing Our Inner Angels and Demons: What We Have Learned About Want/Should Conflicts and How That Knowledge Can Help Us Reduce Short-Sighted Decision Making." Perspectives on Psychological Science 3 (4): 324-338.

Nickerson, David W., and Todd Rogers. 2010. "Do You Have a Voting Plan? Implementation Intentions, Voter Turnout, and Organic Plan Making.” Psychological Science 21 (2): 194-199.

O'Donoghue, Ted, and Matthew Rabin. 1999. "Doing It Now or Later." American Economic Review 89 (1): 103-124.

Osterberg, Lars, and Terrence Blaschke. 2005. "Adherence to Medication." New England Journal of Medicine 353 (5): $487-$ 497.

Reis, Ricardo. 2006. "Inattentive Consumers." Journal of Monetary Economics 53 (8): 1761-1800.

Rogers, Todd, and Katherine L. Milkman. 2015. "Reminders through Association." Working Paper.

Thaler, Richard. 1985. "Mental Accounting and Consumer Choice." Marketing Science 4 (3): 199-214.

Thaler, Richard H. 2015. Misbehaving: The Making of Behavioral Economics. New York: W. W. Norton \& Company.

Thaler, Richard H., and H. M. Shefrin. 1981. "An Economic Theory of SelfControl." Journal of Political Economy 89 (2): 392-406.

Wood, Wendy, Leona Tam, and Melissa Guerrero Witt. 2005. "Changing Circumstances, Disrupting Habits." Journal of Personality and Social Psychology 88 (6): 918-933. 